\title{
The Chinese and Kazakh Languages Comparative Study: Subject-Predicate Sentence Structure
}

\author{
Nurhalyk Abdurakyn \\ Al-Farabi Kazakh National University, Kazakhstan \\ Alina Nurzhayeva \\ Al-Farabi Kazakh National University, Kazakhstan \\ Anar Mustafayeva (Corresponding author) \\ Al-Farabi Kazakh National University, Kazakhstan \\ E-mail: Anar.Mustafaeva@kaznu.kz \\ Dariga Kokeyeva \\ Al-Farabi Kazakh National University, Kazakhstan \\ Kaldybay Kydyrbayev \\ Al-Farabi Kazakh National University, Kazakhstan
}

Received: 14-08-2016

Published: 10-12-2016
Accepted: 17-10-2016

doi:10.7575/aiac.ijalel.v.5n.7p.197
Advance Access Published: November 2016

URL: http://dx.doi.org/10.7575/aiac.ijalel.v.5n.7p.197

\begin{abstract}
This article compares subject-predicate sentence and subject-predicate-object sentence forms with extended sentence of the Kazakh language. It compares Chinese and Kazakh sentences with subject-predicate sentence structure and studies differences of verb-predicate sentences word order. Detailed comparative study of Chinese and Kazakh language differences and characteristics. Morphology structure of Chinese language belongs to radical language, and Kazakh language belongs to the type of adhesive language, syntax of Chinese and Kazakh Languages in the same syntactic structure often used in different ways, the morphological role in Chinese and Kazakh language is also not the same, and even the same kind of grammatical means in Chinese and Kazakh languages are various. According to the analysis of languages, the different positions of word order, the function of words and grammatical word order are different too. The same syntax is very considerable, and lead to different syntactic structures. Chinese thinking reflects the realities as follows: subject - action- object. It is reflected in the grammatical structure: Subject - predicate - object. Kazakh thinking reflects the realities as follows: subject - object - action. It is reflected in the grammatical structure: Subject object - predicate. Chinese and Kazakh predicate and object places in a sentence are different, but their dominance relationship is the same.
\end{abstract}

Keywords: Chinese, Kazakh, word order, predicate sentence, predicate-object sentence, nominative, non-nominative

\section{Introduction}

This article studies the grammatical structures of two different languages Chinese and Kazakh, namely a predicate sentence. Chinese as SVO (Subject - verb - object) language has the subject before predicate, adverb, and then the object and complement. The word order: (attributive) - subject - [adverb] - predicate - verb - (attributive) - object (complement), namely SVO. For example: 咱们 (subject) - 顺便 (adverb) - 问候 (verb) - 一下 (complement) - 她 (adjective) - 吧! - Let's regard her! (subject-adverb-verb-complement-adjective). In SOV(Subject - object - verb) type Kazakh language the subject can be looming, the main person and number can be hidden and represented by a verb suffix after. Word order: (attributive) - subject - (attributive) - object - [adverb] - verbal predicate, namely SOV. For example: Мен (subject)-белімді (adjective)-белбеумен (adverb)-тартып (adverb)-буындым (verb). - I have tightened my belt. (subject-adjective-adverb-adverb-verb).

The examples above show us clearly the differences of two languages word order. The article continues to indicate different points: the name of the same grammatical unit or the actual content is different in the two exactly the same sentences of the languages their expressions and grammatical function also makes a difference. Subject-predicate sentence in Kazakh Nominal Predicate Sentence have nominative and non-nominative distinction, the Chinese do not have this distinction. A single word in the Kazakh nominative sentence has equivalent in the most Chinese verb-object verb-predicate sentence. Adjective-predicate sentence of Subject-predicate sentence includes only the words that form adjective-predicate, adverbial - adjective-predicate, adjective-predicate - compound and complement - adjectivepredicate sentences. Adjective has no "class" changes. If to represent the different levels, the front overlapping degree of adverbial - adjective or adjective can be used. The Kazakh adjectives have "class" changes. The adjective and 
complement phrase of Chinese complement - adjective-predicate sentence of adjective-predicate sentence is a predicate sentence.

Because there is no complement in Kazakh language, so-called adjective-predicate - complement sentence confined in Chinese. Chinese complement of complement - adjective-adverbial sentence is generally equivalent to Kazakh adverb. Verbal-predicate sentence of Subject-predicate sentence includes nominal - verb-predicate, verb-object - verbpredicate, adjective - verb-predicate, verb-predicate - compound, verb-predicate - complement, verb-predicate combined, in Kazakh the subject is generally has persons, number, tenses morphological changes, while Chinese verbpredicate sentence has no morphological changes.

Chinese and Kazakh related in habit of expression and speech. Chinese monosyllabic transitive verb in a sentence generally used with object, if not to add an object, then complement or adverb should be added. Furthermore, Kazakh verb has voice changes, the Chinese do not.

The same point in both languages is to master the predicate sentence one should be interested and should develop the skills: according to hierarchy Chinese and Kazakh simple sentence can be the subject- and non-subject - verb-predicate sentence. If to compare the Chinese and Kazakh predicate sentences we will find out that generally the subject is placed in front and the predicate behind, which is common with Chinese and Kazakh sentence, is also essential foundation.

Chinese and Kazakh Language predicate sentence can be summarized as Nominal - predicate sentence, adjective- and verb-predicate sentence.

Chinese Kazakh non-predicate sentence can be summarized as noun, adjective, verbal and sigh sentence. That shows that the Chinese and Kazakh Language Systems are common. The words of Chinese and Kazakh Language subjectpredicate sentence of nominal sentence correspond to each other. Kazakh nominative single-verb-word sentence is equivalent to Chinese verb-object - verb-predicate sentence.

This proves that the predicate sentence of the two languages have the same points as well as different points on the structure and word order.

\section{Method}

This article compares Modern Chinese and Kazakh languages predicate sentence structure, mainly using the "two triangle" theory, comparative linguistics theory of Three Levels, full description and summary of the similarities and differences between the two languages, and analyzes their causes. Comparative analysis and systematic analysis of similarities and differences between the two languages - Chinese and Kazakh. We hope that the article will help Chinese-Kazakh bilingual learners and researchers to provide references for further more comprehensive and in-depth understanding of modern Chinese and Kazak subject - verb-predicate sentence structure, and foreign language teaching.

\section{Results}

Kazakh language has SVO-type word order. Its syntactic structure is subject, object, adverb and the other parts of sentence are before the predicate verb sentence, the syntactic structure of subject, object, adverb, and other components of syntactic predicate to form multicomponent identity of word order, so to distinguish between the different components of syntax you need to rely on function words and symbols (signs). Various syntactic elements have relatively fixed mark, so the word order is more flexible. Regardless of how word order changes the subject and predicate position will not change. The subject of Kazakh passive sentences as well as Chinese is the recipient, but the doer generally does not appear, the verb is dynamic. The doer must appear with a special particle and case. Different ethnic languages have different ways of conceptualizing. Kazakh verb conceptualization is more complex, rich, and has relatively simple expression syntax. Chinese verb conceptualization distinctive personality, conceptualization of an action is relatively simple, does not consider the direction, location, results and other factors, so when there is a need to express direction, location, results, etc. in a sentence it is needed the help of other words meaning the concept of supplements, grammar expressions and unlike Kazakh language is much more complex.

Chinese and Kazakh subject-predicate structure comparative study discusses every aspect of the subject-predicate sentence. Grammarians have certain criteria to determine the scope of subject-predicate sentence ranges: Sentence statistical and teaching factors research.

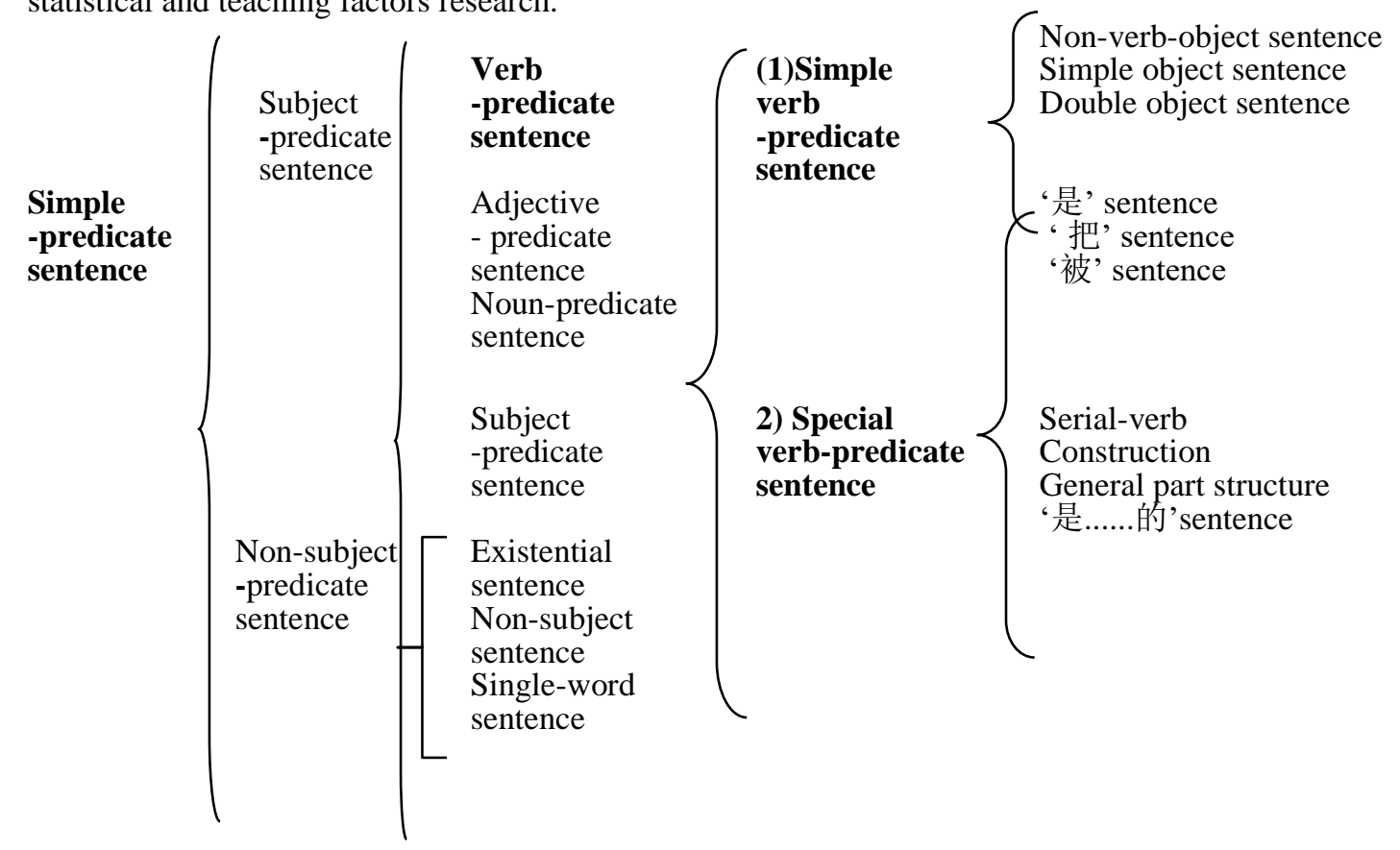


Huang Borong, Liao Xudong in his book "Xiandai Hanyu" 2004 updated third edition (Huazhong shifn daxue chuban) argues that the subject-predicate sentence is made of two parts the subject and predicate. (Subject-verb phrase is the basic element of the sentence). For example: He came. Depending on the predicate sentences, subject-verb sentences can be divided into noun-predicate and verb-predicate sentences (including serial-verb, general-part, double object sentences, ‘把' sentence, ‘被' sentence, existential sentence) predicate adjective sentence, predicate sentence.

According to the structure relation of sentences:

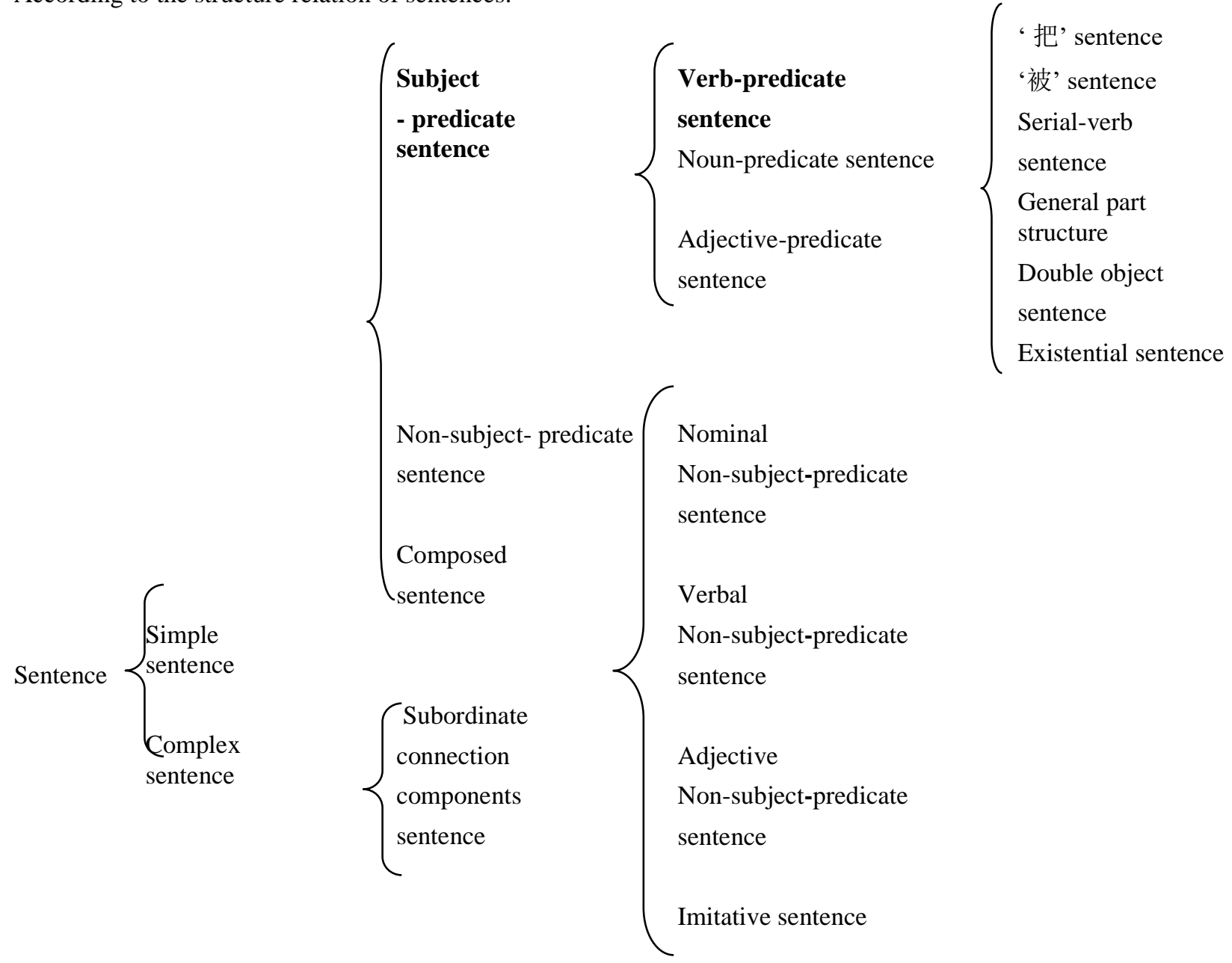

\section{Discussion}

Kazakh language is a part of Altai Turkic language family, Chinese language belong to the Sino-Tibetan language family. Chinese grammar is invisible, Kazakh syntax is visible. Chinese grammar is inseparable from semantics, but Kazakh-based form. Parsing can be completely out of the semantic relationships. Structure figured out, figured out the meaning of a sentence. Its analysis is the process of "structure - semantics"; and each component of Chinese no morphological markers, should only start from the semantic segmentation, sentence structure is the result of semantic analysis. Its analysis is the process of "semantic - structure." Analysis of the verb that statement is also true. As previously mentioned, Kazakh verb suffix plus various additional components can express person, number, type, time, body etc. grammatical meaning. Word phrases and sentences boundaries at a glance. For example: Бap - (go) is this word;

Мектепке бару (go to school) is a phrase; Мектепке бардым. (I went to school.) Is a sentence. "Бар" in phrases and sentences in both morphological changes. The Chinese "go" no change, only by semantic and other sentence elements to determine its structural relationship. So in Chinese "means of synthesis" are important, and in Kazakh "form of synthesis" are important. Han ethnic important thinking "parataxis" important thought Kazak "perception". When expressed in Chinese often give listeners and readers to leave room for his insight, and Kazakh must be clearly represented. Kazak people to learn Chinese language between Chinese and Kazakh languages psychological differences bringing difficulties.

\subsection{Chinese and Kazakh language subject-predicate sentence structure comparative study}

\subsubsection{Comparison of Chinese and Kazakh subject-predicate sentence}

Kazakh language is a part of Altai Turkic language family, Chinese language belongs to the Sino-Tibetan language family. Chinese grammar is invisible, Kazakh grammar is visible. Chinese grammar is inseparable from semantics, and Kazakh is based on form. Parsing can be completely out of the semantic relationships. If the structure is figured out, than the meaning of a sentence is also figured out. Its analysis the process of "structure - semantics"; and each component of Chinese has no morphological markers, it should be only started from the semantic segmentation, and sentence structure is the result of semantic analysis. Its analysis the process of "semantic - structure." Analysis of the verb should be made the same way. As previously mentioned, Kazakh verb suffix plus various additional components 
can express person, number, type, time, body etc. grammatical meaning. Phrases and sentences boundary can be noticed at a glance. For example: Бap - (go) is a word;

Мектепке бару (去学校/go to school) is a phrase; Мектепке бардым. (我去学校了/I went to school) is a sentence. "Бар" has morphological changes in both phrases and sentences. The Chinese "去" (go) has no changes, only by semantic and other sentence elements its structural relationship can be determined. So the important criteria in Chinese is "identity of the meaning", and in Kazakh is "identity of the form." Thus for Han ethnic important is "parataxis", for Kazakhs - "perception". In Chinese listeners and readers are often given a chance to understand the expression by themselves, and in Kazakh they must clearly understand it. Psychological differences between Chinese and Kazakh languages bring greater difficulties to Kazakhs who learn Chinese.

4.1.2 The same points of Chinese - Kazakh subject-predicative sentence

Chinese and Kazakh languages belong to two different types of language, in the structure type Chinese and Kazakh have their own characteristics. Morphological structure of Chinese belongs to the radical language, and of Kazakh language belongs to the adhesive type o language on, therefore, Chinese and Kazakh languages grammar tools often are used differently in the same syntactic structure, Chinese emphasis on the use of words and word order function, such as grammatical tools, the Kazakh tools mostly use forms. The same grammatical role in Chinese and Kazakh language tools also of different sizes, and even the same kind of grammatical tools specific manifestations in Chinese and Kazakh languages are not the same. In the analysis of the language, the role of word order is very important, appearing in different locations each grammatical unit will lead to different syntactic structures. In the form of well-developed language, various syntactic relationship depends mainly on word to represent morphological changes, the role of word order is different. Because of different ethnic cultures, their points of view and reactions are varying considerably. Therefore, the nation-specific plays a big role in thinking and reflecting on the reality. Han ethnic sequence element reflecting: subject - behavior - guest. It is reflected in the grammatical structure: Subject - predicate - object. Kazakh thinking reaction sequence elements of reality is: subject - object - behavior. It is reflected in the grammatical structure: subject - object - predicate. Chinese and Kazakh verb and object word orders are different, but their dominance relationship is the same. Therefore it remains to be the same structure as the comparison. Chinese and Kazakh language simple sentence structure has roughly the same classification, the simple sentence formed by the main component that is the basic sentence; in Kazakh it is called an Non-extended sentence. In addition except the main component there is also other minor component of a simple sentence that is extended sentence and in Kazakh language it also called extended sentence. A sentence include subject variable, and only when the predicate variable is able to confirm the subject it is called the indefinite-personal sentence. There is no exact Person Subject, the person cannot be seen from the Personal predicate form, or, though logical subject, and the predicate does not complex with personal sentence, but with impersonal sentence. The subject of this sentence is difficult to find. Complete sentence: the complete sentence includes all the related to each other components making a sentence, the sentence doesn't divide into primary and secondary sentence components. Sentence elements compose complete sentences. Incomplete sentence: the incomplete sentence does not include all the related components, but there is a sentence with omitted component. Sentence elements compose incomplete sentences. This sentence contains the command, calling, complementary fragments and sigh fragments.

(1) Chinese and Kazakh Simple Sentence with its main structural levels can be described as subject-predicate sentence and Non-Predication Sentence. If to compare the Chinese and Kazakh language subject-predicate sentence some peculiarities can be found out, such as subject stays before predicate which is common in Chinese and Kazakh sentence and is very essential as well.

(2) Chinese and Kazakh language subject-predicate sentence are nominal-predicate sentence, adjective-predicate sentence and verb-predicate sentence.

(3) Chinese and Kazakh language non-predication sentence are noun sentence, adjective sentence, verb sentence and exclamation sentence.

These constitute the common points in Chinese and Kazakh Language Systems.

(4) Chinese and Kazakh Language the One - Word/ Phrase nominal-predicate sentence of the subject-predicate sentence are mostly correspond to each other. Kazakh nominative form of The One - Word/ Phrase nominal-predicate sentence is equal to Chinese verb-object-verb-predicate sentence. For example:

他父亲是医生。Оның әкесі дәрігер. His father is a doctor.

知识就是力量。Білім- - Күш. Knowledge is power.

安全第一, 劳动第二。Амандық бірінші, жұмыс екінші. Safety first, then labor.

团结就是力量。Ынтымақ -күші. Unity is strength.

他妈妈是老师。Оның мамасы мұғалым. His mother is a teacher.

生命在于运动。Мықты денсаулық дене шынықтыруда. Life is movement.

友谊第一, 比赛第二。Достық бірінші,жарыс екінші. Friendship first, competition second.

(5) Chinese and Kazakh Language subject-predicate sentence and other Chinese and Kazakh sentences correspond basically. 
For example:

哈萨克的前途光明。Қазақтың болашағы нұрлы. Bright future of Kazakhs.

他的口才比我好。Оның сөйлеу қабілеті менен мықты. His speaking is better then mine.

现代青年的前途光明而美好。Қазіргі жастардың болашағы нұрлы әрі көркем. Modern youth has bright and beautiful future.

大学生的前景一片美好。Студеніттерінің болашағы нұрлы. The future of students is bright.

他的身高比我高。Ол менен бійік. He's taller than me.

他的衣服很漂亮。Оның кимі өте әдемі. His clothes are beautiful.

老师的工作很辛苦。Мұғалімның жұмысы өте жапалы.Teachers work is very hard.

妈妈的工资高。Маманың жалақысы жоғары. Mother’s salary is high.

(6) The verb-predicate sentences in Chinese and Kazakh Language subject-predicate sentences basically are the same. Where Chinese and Kazakh Language single word verb predicate sentence, combined predicate sentence, and other Chinese and Kazakh sentences are corresponded basically. For example:

柳条动了。Талдар қозғалды. Trees on the move. 刮风了。Жел тұрды. The wind blew

我看电影了。Мен кино көрдім. I have seen the movie. 她姓赵。Оның фамиласы Жау. Her surname is Zhao.

老赵晒太阳。Лау Жау күнге қақталуда. Lao Zhao is basking in the sun. 下雨了。Жаңбыр жауды. It rains.

我踢足球了。Мен доп тептім. I played football. 小明写作业。Шиау мин тапсырма орындады. Хiaoming have done the homework.

天晴了。Күн ашылды. It’s sunny. 他回家了。Ол үйіне қайтты. He went home.

(7) Chinese and Kazakh language non-predication sentences are the same not only in sentence form, format, definition, and concept, but also in classification of terms. For example:

Noun sentence: 谁?Кім? Who? 谢天谢地! Аллаға шүкір! Thanks God! 请吧! Мархемет! Excuse me! 一路顺 风! Жол болсын! Bon Voyage!

Adjective sentence: 糟糕! Нас басты! That’s terrible! 太棒了! Тамаша! Wonderful! 太好看了。Әдемі. Very beautiful!

太美了。Қандай әдемі. That's beautiful! 真棒! Өте жақсы. Very good! 好帅啊! Қандай айбатты жігіт. What a handsome boy! 多么高啊! Неткен биік! That's high!

Verb sentence: 谢谢! рахмет! Thanks! 万岁! Мың жаса! Long live! 祝你一路平安!Ақ жол тілеймін! Take care!

Exclamation sentence: 唉!Aй! Alas! 哎呀呀!Ойпырай! Oops! 呵!Пақ! Oh! 哈哈! Ха ха! Ha-ha! 我的天! Ойбай! Oh my God!

(8) The classification of meaning of Chinese and Kazakh simple sentence is basically the same, Chinese and Kazakh sentence is divided according to the meaning and tone of the sentence into declarative, imperative sentences, exclamatory and interrogative, and all these sentences correspond to each other. Among them the right-wrong question, special question, elective question, positive-negative question (rhetorical) and other types of questions that correspond to each other.

Difference between Chinese and Kazakh subject-predicate sentences

Chinese and Kazakh grammar rules are different, Chinese grammar uses structural words and word orders, and Kazakh grammar uses morphology more. The grammatical role of the means that are used in Chinese and Kazakh languages also are different, and even the same kind of grammatical means of Chinese and Kazakh languages are not the same. In the analysis of the language, the role of word order is very important, each grammatical unit is appearing in different locations, and it will lead to different syntactic structures. In the form of well-developed language, various syntactic relationships depends mainly on word to represent morphological changes, the role of word order is unlikely. The word order of Chinese and Kazakh verb and object is different, but their dominance relationship is the same. For example: 1 . 他//正在干家务活儿。“Ол үй шаруасын істеуде. Hе was doing housework. Direct translation: 他//家务活儿干”。 He//housework//doing. The example shows us that: location of Kazakh and Chinese predicate simply not the same, so one should give the example to the non-native speakers of Chinese and Kazakh students, when they translate sentences wrong. Comparative study on the subject of two languages at the beginning should be so, therefore, because the two types of languages Chinese and Kazakh are different, so the same definitions of grammatical unit of two languages or the actual content of a sentence is not exactly the same, its manifestations and grammatical functions have difference. If we compare the way of study and structural interpretation, we can explain the common specific differences that were mentioned above.

(1) The subject-predicate sentence of Kazakh nominal predicate sentence has nominative and non-nominative case difference, but Chinese sentence does not have such difference. Kazakh nominative forms of independent body of predicate sentences are most equal to Chinese verb-object-verb-predicate sentence. For example:

Оның шешесі мұғалім. 他的母亲是老师。His mother is a teacher. 
Ынтымақ一күш. 团结就是力量。Unity is strength.

Оның әкесі сақшы.他的爸爸是警察。His father is a policeman.

Достық жасасын. 友谊万岁。Friendship forever!

Kazakh non-nominative The One - Word/ Phrase nominal predicate sentence generally is equal to Chinese verbpredicate sentence. For example:

Сенің кітабің менде.你的书在我这儿。I have your book.

Ол Астаналық.他是阿斯塔纳人。He is from Astana

Менің кимім үйде.我的衣服在家里。My clothes are at home. Ол шетелдік.他是外国人。He is a foreigner. Сенің кілтің үстел үстінде.你的钥匙在桌子上。Your keys are on the table

The predicate of Kazakh non-nominative The One - Word/ Phrase nominal predicate sentence is the Chinese equivalent of the verb-object-verb-predicate sentence, if it is with the word genitive noun or pronoun. For example:

Бұл менің кітабім. 这本书是我的。This book is mine.Бұл доп оныкы.这个球是他的。The ball is his.

Бұл үй менікі.这个房子是我的。This house is mine. Бұл ит оныкы.这个狗是她的。This is her dog.

If the predicate of non-nominative the One - Word/ Phrase nominal predicate sentence the word with time and from, it is the equivalent of Chinese verb-object-verb-predicate sentence. For example:

Ол мектепте. 他在学校。 $\mathrm{He}$ is at school. Ол үйде.他在家。 He is at home.

Ол кітапханада.他在图书馆。 $\mathrm{He}$ is in library. Ол әмбебап дүкенінде.他在超市。 $\mathrm{He}$ is at supermarket.

Ол алаңда.他在操场。 $\mathrm{Hi}$ is on the playground $\quad$ Ол аудиторяда.他在教室。 $\mathrm{Hi}$ is in classroom.

(2) The adjective predicate sentence of subject-predicate sentence includes the One - Word/ Phrase adjective predicate sentence, adverbial-verb adjective predicate sentence, conjunctive-adjective predicate sentence and Supplement adjective predicate sentence.

Adjective in Chinese has no "class" changes. If the indication degree is different, adjective can be set before the reduplication degree or adverb degree before adjective. The Kazakh adjectives

The "level" changes. For example:

他写的好一些。He wrote better. Оның жазуы жақсырақ.

那条路笔直笔直的。Ана жол түп-түзу. That road is very straight.

他踢的好一点。Ол допты жақсы тебеді. He play football well. 这个苹果圆圆的。Бұл алма дөп дөңгелек. The apple is round. 他跑的快一点。Ол тезірек жүгіреді. He run faster. 那座山高高的。Ол биік тау. The mountain is high. 他长得漂亮些. Ол әдемірек. Hе looks prettier.

Most of adverbial clauses of Chinese adverbial-verb adjective predicate sentence play role of adverb, followed by a prepositional phrase and particle; Most of adverbial clauses of Kazakh adverbial-verb adjective predicate sentence play role of non-nominative nouns, followed by adverbs and postposition phrases. Therefore, the Kazakh non-nominative adverbial-verb adjective predicate sentence is generally equal to the Chinese verb-predicate sentence.

For example:

Ол қырықтың мол ішінде. 他有 40 多岁。 He is over 40 years old

Үйде жан пенде жоқ. 屋子里没有一个人。There is no one in house. Ол көмекке зару. 他需要帮助。 He needs help.

Аудиторяда адам көп.教室里好多人。There is a lot of people in the classroom. Ол жас.他是年轻人。He is a young man.

Оған демалу керек.他需要休息。He needs a rest. Оған ақша керек.他需要一笔钱。He needs money.

The attribute or adverb of Kazakh sentences above can equal to the Chinese subject, Kazakh subject is equivalent to the Chinese object. Such sentences of Chinese and Kazakh have a great difference, which is related to the nature of the predicate, because Kazakh predicate can play role of adjective only with adverb, while Chinese predicate is a verb only with object. For example:

Шымкент Атыраудан үлкен. 石姆肯图市比阿特劳市大。Shymkent is bigger than Atyrau

Бүгінгі ауарай кешегіден жақсы. 今天的天气比昨天好。Today the weather is better than yesterday.

Сенің күшің менен көп.你的力气比我的大。Your strength is bigger than mine.

Оның бойы менен биік.他的个子比我高。He is taller than me.

Астана Алматыдан алыс.阿斯塔纳比阿拉木图远。Astana farther than Almaty. 
(3)Chinese Supplement adjective predicate sentence of subject-predicate sentences is a sentence with adjectival supplement phrase as a predicate. Because Kazakh Supplement adjective predicate sentence has no complement, one can meet complement only in Chinese. Chinese complement of Supplement adjective predicate sentence is generally equivalent to Kazakh adverb. For example: 病情严重极了。Оның ауыруы асқынды. He is very ill.

场地上静得很. Алаң тып-тыныш. It is very quiet outside

生活糟糕透了。Тұрмыс өте нашар. Life is terrible

心情美极了。Көңіл күйі өте жақсы. In a good mood

市区远极了。Қала орталығы өте алыс. City centre is very far from here

天气冷的很。Күн қатты суық. It's extremely cold

风大的很。 Жел қатты. It's very windy

(4) The predicate-verb sentence of subject-predicate sentence includes nominal predicate-verb sentence, verb-objectverb-predicate sentence, adverbial-verb verb-predicate sentence, conjunctive verb-predicate sentence, supplement verbpredicate sentence, verb-predicate sentence with verbs in series, pivotal verb-predicate sentence. The subject of a Kazakh verb predicate sentence generally has several morphological changes, (person, time and form), while Chinese verb predicate sentence has no morphological changes.

Kazakh and Chinese Correspondence relationship is related with Chinese expression habits and parts of speech. Chinese monosyllabic transitive verb in a sentence generally used along with object, if to not use object, then one should add complement or adverb. Furthermore, Kazakh verb has voice changes, the Chinese has no such changes. For example: 哈 瑟木穿衣服了/Hasse wear wooden clothes.

Chinese and Kazakh languages both have verb-object-verb-predicate sentence, but the word order in such a Chinese with Kazakh sentence is different, in Chinese sentence the verb should be set before object; and in Kazakh contrary, object stays the first, and then the verb. For example:

我们能战胜任何困难。Біз кез-келген қиыншылықты жеңеміз. we can overcome any difficulty.

我们能超越自己。Біз бәрін жеңеміз. We will be victorious

他恳求走慢点。Ол ақырын жүруді талап етті. She demanded to go slowly.

他建议公司改革。Ол компаняны өзгертуге ұсыныс берді. He suggested the company to hold some reforms

他命令部队前进。Ол қосынға ілгерлеу бұйрығын берді. He ordered the bureau to make progress.

For comparison we can see, the Chinese verb-object relationship reflects by means of word order: So the nominal which stays after predicate usually play role of object. The Kazakh object generally has morphological marks of objective case "на \ни, да \ди, та \ти, н" verb-object relationship which can be embodied by morphology. Kazakh verb-object-verbpredicate sentence relationship is clear at a glance, subject generally is the actor, object is recipient (of action) of Even sentence and has no object mark, actor-recipient relation is still very clear. This is the difference of Chinese from Kazakh. For example:

Мен кино көрдім. 我看电影了。I watched a movie

Ол хат жазды. 他写信了。He wrote a letter

Ол ұйықтады. 他睡觉了。He slept.

Ол тамақ жеді. 她吃饭了。 She had a dinner.

Ол үйге қайтты. 我回家了。I went home.

Досым емханада жатыр. 朋友住院了。My friend is in the hospital

Әкем жұмысқа шықты. 爸爸上班了。My father went to wok

(6) Chinese and Kazakh adverbial-verb verb-predicate sentence in the syntactic structure of sentences has similarities and differences. The similarity is that Kazakh and Chinese both has adverb in the beginning of a sentence, and the adverb generally is time, place and location. The difference is that Kazakh word order of verb-object structure is different from Chinese, the position of the adverb also has differences. For example:

Today we visited the industry exhibition.

我们今天参观了工业展览。 (adverb - subject - predicate - object)

Біз бүгін өнер кәсіпті тамашаладық. (subject - object - adverb - predicate)

Yesterday we watched the videos. 我们昨天观看了宣传片。Біз кеше үгіт филімін көрдік.

They will enjoy a concert tomorrow. 他们明天欣赏音乐会。Олар ертен музикадан лазат алады.

They played football the last month. 他们上个月踢足球赛了。Олар алдынғы айда доп тепті.

“不、没、别”adverbial words serve as Chinese adverb in the negative adverbial-verb verb-predicate sentence, and modify the verb in the sentence. The Kazakh negative meaning entirely rely on verb stem decorated with negative words. For example: 
我不去。Мен бармаймын. I will not go.

他们没有来。Олар келмеді. They did not come.

你别回家。Сен үйге қайтпа. Do not go home.

我不看电影。Мен кино көрмеймін. I do not watch movies

你没看书吧。Сен кітап оқып жүрген жоқсың. You did not read a book.

你别动。Қозғалма. Do not move.

(7) There is no complement in Kazakh, therefore Chinese Supplement verb-predicate sentence is equivalent to Kazakh adverbial-verb verb-predicate sentence. For example:

他生于 1981 年。Ол 1981жылы туылған. He was born in 1981.

他们合作得非常好。Олардың келісімі өте тамаша. They cooperate very well.

他们争吵的很激烈。Олардың соғысы өте қиан-кескі. They quarrel very intense.

我们过得很快乐。Біз көңілдіміз. We are very happy.

Some Chinese complements of Supplement verb-predicate sentence are equivalent to Kazakh nominal expression meaning, for example:

努尔江的衣服已经破烂了。Нұржанның кимі тозып кеткен. Nurzhan’s clothes are worn out

他们是能想出好办法的。Олар жақсы амал ойлап табады. They find the best way

沙吾列的耳环丢了。Сауленің сырғасы жоғалып кетті. Saule's earrings have been lost

他们会解决这个问题的。Олар бұл мәселені шешеді. They will solve this problem.

我的衣服掉色了。Біздің киімнің өңі түсіп кетті. Our clothes lost colors

我们可以成功的。Біз табысқа жетеміз. We will succeed

(8) Chinese has Sentence with verbs in series, Kazakh has no such sentence. Kazakh every simple sentence has verb with personal predicate. This verb is the predicate of the sentence. If there is some other verb in the sentence, it doesn't change forms, but gerund, participle and cover all are impersonal verbs. Although this parts and the subject have a direct relationship, because there is no reflected in the form, the predicate form can't be structured, therefore is not a predicate of a sentence, and Kazakh simple sentence generally has only one verbal predicate. The Chinese has no morphological marks, the verb is often set in a raw form, and thus a simple sentence often has several verbal predicates. Chinese verb-predicate Sentence with verbs in series is generally equivalent to Kazakh adverbial-verb verb-predicate sentence. For example:

群众听了很满意。Көпшілік естіп риза болды. People satisfied with what they heard

我们坐车去。Біз машинамен барамыз.We will go by car.

孩子们忍不住哭了起来。Балалар шыдай алмай жылап жіберді.The children started to cry.

我激动的哭了。Мен тебіреніп жылап жібердім. I started to cry.

我们跑步回。Біз үйге жүгіріп келдік. We run back home.

工人看了很高兴。Жұмысшылар көріп өте куанды. Workers looked and became very happy.

我们走着去。Біз жаяу барамыз. We will go by foot

(9) The Chinese have Pivotal verb-predicate sentences with Pivotal phrases as predicate. Kazakh language has no Pivotal verb-predicate sentences. But that Chinese sentence can be indicated in Kazakh with different types of sentences. For example, Chinese Pivotal verb-predicate sentences can be equal to Kazakh adverbial-verb verb-predicate sentence:

请你带我去车站办事处好吗? Сіз мені вагзалдың іс басқармасына ертіп баршы. Please take me to the station office, okay?

他的话叫我想起了过去。Оның сөзі маған өткен күндерді есіме салды. His words reminded me of the past.

请你帮我带回家好吗？Үйге ала кетсен болама? Please help me get back home, okay?

他的歌让我幻想起未来。Оның әні болашақты елестетті. His songs make me imagine the future.

Chinese Pivotal sentences equal to Kazakh verb-predicate sentence. For example:

这事叫人担心。Бұл іс адамды алаңдатады. This thing makes one worrying.

你不要再让我们受怕了。Сен бізді ендгіары қорқытпа. Do not threaten us anymore.

你们不要再让我笑了。Мені күлдіре бермендер.

这事叫人震惊。Бұл іс адамды шошытады. This thing is shocking

你不要再让老师说了。Сен мұғалімді тағы мазалама. Do not bother the teacher anymore 
(10) Kazakh tethered verb-predicate sentence immediately constituents to a tethered component, and the other is formulating component, structure order is generally as follows: formulating component set before tethered component. Kazakh tethered component act as copula linking verb "еді, екен, емес, бол, кел" and etc.

Chinese has no tethered verb-predicate sentence.

Most of Kazakh tethered verb-predicate sentence equals to Chinese verb-object verb-predicate sentence. For example:

Сіз кім боласыз? 你是谁? Who are уоu? Бұл тас бес кило шығады. 这块石头有五公斤。 The stone is about five kilograms.

Бүгін күн суық емес. It is not cold today. 今天不冷。

Кеңседе жан баласы жоқ. 办公室里一个人也没有。

There is no one in the office. Ертен ыстық болмайды. 明天不热。It will not be hot tomorrow.

There are some Kazakh tethered verb-predicate sentence equals to Chinese adjective-predicate sentence. For example:

Асқардың үйренуі жақсы. 阿斯哈尔的学习好。Askhar is studying well.

Сұрет өте тұнық. 照片很清晰。Photo is very clear.

Қақардын дені сау. 哈哈尔身体好。Hakhar has a good health.

Дыбысы керемет. 歌声很动听。One is singing very well

Тұрмыс өте тамаша. 日子很红火。Life is wonderful

(11) The predicate of a sentence with a subject-predicate phrase as predicate is generally has four types of phrases, such as substantive, adjective, verbal and subject-predicative phrases. The Kazakh Predicate predicate of a sentence with a subject-predicate phrase as predicate is generally has three types of phrases, such as substantive, adjective and verbal phrases. Chinese predicate Kazakh is equivalent to verb-object verb-predicate sentence. For example:

Менің айтып отырғаным сөз бір құлақ екі. 我所强调的是好话只说一遍。 I have to emphasize that only good things to say again.

Менін ақылым, адам көп болса күш көп болады. 我所建议的是人多力量大。My model is strength in numbers.

Менін қолдайтыным ортаны қорғау. 我所倡导的是保护环境。 I advocate is to protect the environment.

Chinese adjective predicate Kazakh is equivalent to adjective-predicate sentence. For example:

Менің денсаулығым жақсы. 本人身体健康。 I am healthy.

\section{Оның түрің басқаша.他的长相出众。He looks different}

Chinese verbal predicate Kazakh is equivalent to verb-object-verb-predicate sentence. For example:

集体的事大家抢着干。Көпшіліктің ісін адамдар таласа тармаса істеді. Everyone vie with each other for the social business .

(12) The head driven phrase of Kazakh Non-Predication Sentence according to the nature of can be divided into noun sentence, adjective sentence, verb sentence and exclamation sentence. The main difference between two types of sentences is: attribute of Chinese noun and adjective sentences should be used with "的", and Kazakh language beside speech means grammar, generally has the head driven phrase changes, using morphological means. For example:

在你的国家。Сіздің еліңізде. In your country.

谢谢您的盛情。Ілтипатыңызға рахмет. Thank you for your kindness.

谢谢你的好意。Сіздің ықыласыңызға рахмет. Thank you for your intentions

在我的故乡。Менің туған жерімде. In my hometown.

感谢你的邀请。Шақырғаныңа рахмет. Thank you for your invitation.

The ways of constructing phrases in both languages are different: (verb-predicate sentence as subject)

Overall, the position of core predicate in the two languages is different. Their word order as follows: subject - predicate - object. Kazakh: subject - object - predicate.

4.1.3 Chinese and Kazakh word order in verbal predicate sentence.

The main difference between Chinese and Kazakh word order in verbal predicate sentence

(1) The general word order in verbal predicate sentence

Chinese is a SVO-type of language, its morphological markers system is relatively simple, mainly by means of analytical represent various grammatical categories. The subject and adverb are set before predicate, the object and complement - after predicate. The basic components of the sentence is clear due to the word order, there is no need in a special tag to represent their semantic roles:

(Attribute) - subject - [adverb] - verbal predicate - (attribute) -object -(complement), = SVO. For example:

咱们一顺便一问候一一下一她一吧! (subject-adverb-verb-complement-object) 


\section{Let us question her!}

Kazakh is a SOV-type language, there are more complex forms of the marking system. It is marked by a variety of means to form grammatical category. The parts related to verbal predicate are set before the verb. The suffix with grammatical meaning of verb. Sometimes when a topic is needed to be changed, object might be set before subject, it will not cause misunderstanding. Because accusative marker has demonstrated its semantic roles. Subject can be hidden by person and number, and can be set after verbal suffix:

(attribute) - subject - (attribute) - object -[adverb] - verbal predicate $=$ SOV. For example:

Мен-белімді-белбеумен-тартып-буындым. (subject-object-adverb-adverb-verb)

I tied up the belt

(2) A special word order in verbal predicate sentence

When a speaker wants to achieve a certain effect of expression, often makes changes in word order, or omits certain components of them. There are several changes in the case of word order:

1. Omission: Omission occurs in provincial dialogue context. Omission requires language to be understandable; otherwise it will cause the wrong sentence. Chinese and Kazakh omission of predicate, object, attribute, adverb is basically the same. But the omission of the subject varies. Because of the absence of it in Chinese, statement cannot omit the subject; and Kazakh verb-predicate sentence can be omitted from the first and second person pronouns serving as the subject. For example:

我明天去阿斯塔纳。 *明天去阿斯塔纳。

Мен ертең Астанаға кетемін. — Ертең Астана жаққа кетемін.

我明天阿斯塔纳我去——明天阿斯塔纳我去

I will go to Astana tomorrow - Tomorrow to Astana I will go

你明天去阿斯塔纳。一 $*$ 明天去阿斯塔纳。

Сен ертең Астанаға кетесін. —— Ертең Астана жаққа кетесің.

你明天阿斯塔纳你去。—明天阿斯塔纳你去

You will go to Astana tomorrow - Tomorrow to Astana you will go

您高寿了?——高寿了?

Сіз қанша жасқа келдіңіз_- Қанша жасқа келдіңіз?

您多少岁到——多少岁您到

How old are you? - How many years you come to?

我们一定要把你们的经验带回去。———定要把你们的经验带回去。

Біз сіздердің тәжирбиелеріңізді алып бара жатырмыз.

我们你们的 把经验—向我们自己地方拿回去

We will use your experience - We your experience will take with us

Kazakh is an agglutinative language. Such additional components as person, number, body, state, or time can be added after the verb, and the person, the number is consistent with the subject. First, when the second person pronoun serves as subject verbal suffix is set after verbal predicate, thus verb serves as subject-person. Therefore, even if there is no adverbial modifier, it can be indicated with verbal predicate suffix. When the third person pronoun serves as subject, though it may also be indicated with verbal suffix, but in the case of the absence of the prefix and ending, the omission of the third person subject can cause misunderstanding. Therefore, the third person subject cannot be omitted. Chinese verb predicate has no morphological changes, cannot clearly show an action of the main body, thus in the case of the absence of the prefix and ending, the omission of the subject is impossible. For example:

叶尔咩克看见一个人从对面走过来了。

Ермек қарсы алдынан бір кісінің келе жатқанын көрді.

Ermek saw a man coming up from the opposite.

叶尔咩克从对面一个人的 把正走过来看见。

*Қарсы алдында бір кісінің келе жатқанын көрдім.

从对面一个人的 把正走过来 看见

From the opposite a man coming up I saw

2. Inversion: Inversion is inverting the original word order to enhance heightened effect, with strong tone and pause added in the middle.

(1) The subject-predicate inversion: predicate is placed before subject. Both Chinese and Kazakh have this form, and generally correspond. For example:

真苦啊, 这个。Ашты екен, мынау. This is really bitter 
苦这个起来, 饥寒交迫的奴隶。Қозғал ашта жалаңаш құлдар. Slaves suffering from hunger

Кет, сен! 走你走开, 你! Get away, you!

Мен барам, мен. 我去我去了, 我。I will go, I will go!

(2) The predicative object inversion: object is placed before predicate verb. Because the basic word order in two languages is different, so when verb and object invert in Kazakh, in Chinese it is a common sentence. For example:

Тарт қолыңды! 拿开把你的手/拿开你的手/把你的手拿开! Don' touch me!

Лақтырып таста, андағыны. 扔掉/把那个扔掉那玩意儿! / 把那玩意儿扔掉! Throw it away!

When the Chinese object is set before verbal predicate, sentence changes to subject-predicate predication sentence. Kazakh changes to common subject-predicate sentence. For example:

Example 1

你拿我的书了吗?一龵的书你拿了吗?

Кітабымды алдың ба? Did you take my book?

把我的书你拿了吗? Book took you?

Example 2

他烧掉了落叶。——他把落叶烧掉了,

Ол жерге түскен жапырақтарды күйдіріп жіберді. He burned fallen leaves

他 落下的 把叶子烧. He fallen leaves burned

他脱掉了鞋子。-------他把鞋子脱掉了。

Ол Аяқ киімін шешті. He put off his shoes

他鞋脱了 He shoes put off

你回家了吗?------家你回了吗?

Сен үйге қайттың ба? Are you going back home?

你家回了吗? You home back?

"My book" in Example 1 and "leaves" in Example 2 in the sentence are recipients (of action). But if they were before verb they wouldn't be object, but subject or adverb: in Example 1 sentence has changed on a subject-predicate predication sentence, and to “把”sentence in Example 2.

(3) The adverb-predicate inversion: Both Chinese and Kazakh adverb stays before verbal predicate. Adverbs of time may appear before the subject. Sometimes because of the emphasis of predicate action adverb can be placed after the predicate.

Both Chinese and Kazakh have this expression, and mostly they are corresponding. For example:

Мен бардым кеше. 我去了昨天。/我去了, 昨天。I went yesterday

Оның жазуы түзеліп қалар бірте-бірте. 他的字 被改正慢慢地。/ 他的字写得顺溜儿了, 慢慢地。His writings are corrected slowly.

From the comparison shown above it is clear that Chinese is a SVO language, by analysis has been determined the specific lack of morphological characteristics in the verb-predicate sentences, with the basic word order: "accompanying feature + head driven predicate + resulting adverb". Kazakh SOV type has the typical features of the language, its syntactic structure is subject, object, adverb and other parts of sentences are set before verbal predicate, thus forming a variety of word order structures, and therefore rely on the particle and clause to distinguish the various syntactic elements. Due to various syntactic elements have relatively fixed mark, it has relatively more flexible word order. However, the relationship between subject and predicate any time is the same.

In general, because of different ethnic cultures, their points of view and reactions are varying considerably. Therefore, the nation-specific plays a big role in thinking and reflecting on the reality. Han ethnic sequence element reflecting: subject - behavior - guest. It is reflected in the grammatical structure: Subject - predicate - object. Kazakh thinking reaction sequence elements of reality is: subject - object - behavior. It is reflected in the grammatical structure: subject object - predicate. Therefore, due to the interference of mother tongue, Kazakh students who lean Chinese have problems with using Chinese subject-predicate sentences.

\section{Conclusion}

Xiang Lin Mei (1990) and Fu Huijun (2004) think that the subject-predicate sentence can be divided into noun-, verb-, adjective- and subjects-predicate sentences. According to the sentence characteristic, there are a lot of special sentences. For example: ‘把' sentence, ‘被' sentence, “是' sentence, existential sentence, etc。Lufu Bo (2001) supposes that: modal verbs belong to a special category of sentences. Xu Shao Jian (2003): subject-verb sentence can be divided into noun-, verb- (including serial-verb construction, general part structure, double object sentence, '把' sentence, ‘被' sentence) adjective-, subject-predicate, and existential sentence. Fan Xiao (Beijing Commercial Press, 2009) in his book divides Chinese sentences into subject- predicate, verb-predicate, adjective-predicate, noun-predicate, subject - 
predicate sentences. Huang Borong, Liao Xudong are editors of "Modern Chinese" 2004 third edition (Higher Education Press). This book argues that subject-predicate sentence consists of two parts the subject and predicate. (The basic component of subject-verb phrase of the sentence is subject-predicate sentence). For example: Ол келді. - Не came. According to the difference of predicate sentences, the subject-verb predicate sentence can be divided into noun-, verb- (including serial-verb construction, general part sentence, double object sentence, ‘把'sentence, ‘被' sentence, existential sentence) adjective-predicate sentence.

Xing Fuyi, Wu Zhenguo consider in "Yuyan xue gailun" 2005 that subject- predicate sentence is double part of this sentence which meets in any languages. The subject - verb predicative sentence can be divided and nominal sentence. According to the presence or absence of the object the sentence can be divided into three categories and the number of non-object sentence, single object sentence, double object sentence. Characteristics of some sentences structure have specifics. For example: subject-verb-predicate sentence, '把' sentence, ‘被' sentence, existential sentences, etc. Xing Fuyi (2011) write about predicate: the predicative verb-predicate is very common, the verb as predicate is more common. For example: subject-predicate phrase, general phrases, double object phrase, verb-object phrases, etc. According to Xing Fuyi and Wang Guosheng (2010.3) phrases and simple sentence structure is substantially the same. Subject-predicate, verb-object, official, description supplement type, etc.

Generally, predicate of subject-predicate sentence is the core of modern Chinese sentence structure and therefore the structure of the type of predicate, subject-verb sentence: noun-predicate, verb-predicate (including serial-verb construction, general part sentence, double object sentence, '把'sentence, ‘被' sentence, existential sentence), adjective-predicate, subject-predicate sentences. The function of predicate of modern Kazakh subject-predicate sentence is divided personal, non-personal, extended and non-extended, complete and incomplete, nominative sentences. According to predicate construction, both languages have the verb as the center word of verb-predicate sentence, but both do not exactly correspond, Chinese special verb predicate sentence cannot be found in Kazakh.

\section{References}

Abdurakhyn N. (2010). Xiandai hanyu yufa. Almaty: KazNU.

Ahanov K.A. (1996) Khazirgi khazakh tili gramatikasy. Almaty, 239

Akhmet, B. (1921). Klassifikaciya predlozhenii v kazakhskom yazyke. Almaty: Mektep.

Amanzholov. D. (2004). Khazirgi Kazakh tili. Almaty: Mektep.

Amanzholova, S., Amanzholov, A., \& Kosymova. G. (2012). 8 synyp okulygy. Almaty: Mektep

Chen, M. (2008). Tici weiyu ju yanjiu. Beijing: Zhongguo wenlian.

Ecenov, H. (1974). Kazakh tildin kurmalas soilemder. Almaty: Mektep

Ermekova, T. (1999). Imennoe skazuemoe predlozhenie v sovremennom kazakhskom yazyke. Almaty: Mektep.

Fan, X. (2009). Hanyu juzi de duo jiaodu yanjiu. Shangwu yin shuguan.

Huang B., \& Liao, X, (1997). Xiandai hanyu. Zhending erban. Beijing: Gaodeng jiaoyu.

Huang, B., \& Liao, X. (2004). Xiandai hanyu. Zhengding sanban. Beijing: Gaodeng jiaoyu.

Iskakov, A. (1974). Grammakita sovremennogo kazakhskogo yazyka. Almaty

Kacymova, G. (2007). Kazakh grammatikasy. Almaty

Kenesbayeva, I. (2010). Issledovanie kazakhskogo yazyka. Pavlodar.

Khalibekuly. (2004). Xiandai hanyu yufa. Cihui bu. Almaty, 197.

Lü. Sh. (1980). Xiandai hanyu babai ci. Shangwu yin shuguan.

Meliorance, P.M. (1917). Vvodnyi kurs v kazakhskii yazyk. Almaty.

S.Isayev, K.N., \& Dauletbekova, Zh. (2011). 6 synyp okulygy. Almaty: Atamura

Sadvakasova, F. (1996). Prostye predlozheniya sovremennogo kazakhskogo yazyka. Almaty.

Sairambayeva, T. (1991). Juzide zhuyao chengfeng. KazNU

Shaykenova, K. (1995). Leksicheskie i logicheskie svyazi. Almaty

Xing, F. (2010). Xiandai hanyu. Beijing: Gaodeng jiaoyu.

Xing, F., \& Wang, G. (2010). Xiandai hanyu. Beijing: Gaodeng jiaoyu.

Xing, F., \& Wu, Zh.. (2005). Yu yan xue gailun. Beijing: Shifan daxue.

Zhang B. (2002). Xinbian xiandai hanyu. Shanghai: Fudan daxue. 